coast, where irrigation is available. These will be the sites of piggeries, where the grain sorghum will be fed to outdoor pigs. It is intended that each unit shall carry some 200 breeding sows. The number of units which will finally be developed is dependent upon experience gained with the first experimental units and on the future trend in coarse grain prices.

A third activity of the Corporation is the fattening of store cattle on the sorghum stover and grass of the unploughed areas of the large properties.

It is impossible to give anything but rather vague estimates of the contribution which this scheme will make to the British diet, as the form in which our products will be exported to Britain will depend on future market movements. It is hoped that after I95 I the Corporation will produce annually an average of some 80,000 tons of grain sorghum. If all this were fed to pigs in Queensland some 200,000 carcasses might be produced annually. It is possible, however, that the pig side of the venture may be developed a little less rapidly than the grain growing, in which case the surplus grain would be shipped to Britain for animal feeding. From this production 6000 tons were shipped home in 1949. Pig-feeding trials with this grain, made by Dr Braude at the National Institute for Research in Dairying, University of Reading, were entirely satisfactory. In addition to the grain or bacon exported, the Corporation will also be fattening off several thousand head of stock for export to Britain.

This, briefly, is the measure of production at which the Corporation is aiming during the next 5 years. As each year goes by, it is hoped to send home increasing quantities of oilseeds, grain sorghum, bacon and meat up to the quantities mentioned. Meanwhile, it is hoped to establish production in East Africa on an economic basis. After that period, with more knowledge of the costs and possibilities, it may be possible slowly to expand that production. Even should that not be feasible, I believe that the Overseas Food Corporation will have made a very real contribution, not only to the diet of the people of this country, but to the fundamental knowledge required for the future development of empty lands in Africa and elsewhere.

\title{
Commonwealth Contributions and British Requirement of Meat
}

\section{By J. Hammond, School of Agriculture, University of Cambridge}

This country will always be dependent on overseas supplies of meat. Before the war approximately $40 \%$ of our meat supplies were imported but, owing to the ploughing up of pastures for wheat and potatoes, to the increase in the dairy industry for the supplying of fresh milk, and to the shortage of imported feeding-stuffs, we are now dependent on overseas supplies of meat to the extent of about $55 \%$.

The general situation as regards consumption here has been changed since prewar days, for the amount consumed is now limited by the rationing system rather than by the price, owing to the application of the food subsidies. During the time of shortages, quality in meat has been at a discount, but signs are now appearing that many people, where supplies have been increased, are failing to take up the ration if the quality of the 
meat is poor. 'They object to paying for meat of which they can eat only a small proportion owing to its leathery texture. 'This discrimination would be accentuated if subsidies were reduced or removed and if meat were derationed. High quality in imported meat will be necessary therefore if adequate consumption is to be maintained in the future.

\section{Beef}

The situation in respect to beef has changed in several ways since prewar days. Beef is no longer sent here from Argentina, our main supplier before the war, as 'interest' on capital invested there, but has to be paid for by exports or in other ways. In this country the dairy industry has been expanded greatly, so that it is taking much of the supplies of winter feeding-stuffs which formerly were used for winter fattening. The importation of feeding-stuffs has been much reduced owing to the difficulties associated with the 'iron and dollar curtains', and this, associated with the recent increase in price of sugar-beet pulp, the main winter feed for fattening cattle, has tended to make our beef supply more seasonal, most of it now being produced off grass in the autumn. Overseas supplies of beef to supplement the home production are, therefore, likely to be most welcome from January to July unless more adequate cold storage space can be provided in this country for supplies arriving at other times. The possible supply of groundnut cake and other feeding-stuffs from overseas would do much to improve the beef production of this country. It is to be hoped too that increased supplies of beef from the efforts now being made in Australia will not be too long delayed.

\section{Mutton and lamb}

Very much the same changes have taken place with mutton and lamb as with beef, and it is from January to July that supplies are most needed from overseas to ensure an even supply throughout the year. But for the increased supplies which have come from New Zealand in recent years, we should have been very badly supplied with mutton and lamb, and it is good to hear that we may expect to have an increase in the amount from Australia in the near future. More cold storage space is again necessary if an even supply is to be maintained all the year round. In countries like Australia and South Africa, as we have heard, a seasonal drought is liable to reduce supplies in certain years; it would seem, therefore, that additional cold storage space to maintain a reserve would be a wise provision if we are to depend on supplies from such sources.

\section{Pork}

Supplies of pork are now almost negligible in this country, since the home-bred pigs have been used almost entirely for bacon (Callow, 1950). Before the war about half our pigs were used for pork, but the loss of much of the feeding-stuffs then used for pigs, mainly maize, and wheat-milling offals from white bread production, has reduced the numbers considerably so that they are now sufficient only for bacon. From this fact and from what we have heard in the papers read this morning (Heywood, 1950; Hopkirk, I 950; Robertson, 1950) the outlook for future pork supplies in this country is very black. Supplies of pork from the continent of Europe are now being considered, but 
they entail the great risk of possibly introducing foot-and-mouth disease or swine fever which might endanger the whole animal industry here. There is more need for supplies of pork from overseas than of any other product. Before the war large quantities of frozen pork came from New Zealand and Australia and it is to be hoped that the difficulties there will soon be overcome. The possibility of pork from South Africa (van der Post, 1950) gives a ray of hope and, if the dollar problem could be solved, Canada could do a lot to help in this respect. Stepping up home production is entirely a matter of supplies of feeding-stuffs, and possibly the sorghum from Australia, and soya-bean by-products, if their production is a success, from Africa, will be a means of solving our worst problem of meat supplies.

\section{Poultry-meat}

The consumption of poultry-meat in this country, unlike that of other classes of meat, is limited by price rather than by coupons. At present considerable supplies are coming from continental Europe but here, again as with pigs, there is considerable risk to our own poultry industry from the introduction of fowl pest. It is, therefore, good to hear that increase in supplies from Australia is likely (Heywood, 1950). To what extent this trade will develop depends largely on price for, unlike with other meats at the present time, the amount consumed depends on price to the consumer.

\section{REFERENCES}

Callow, E. H. (1950). Brit. F. Nutrit. 4, 82.

Heywood, R. H. (1950). Brit. Y. Nutrit. 4, 53.

Hopkirk, C. S. M. (1950). Brit. J. Nutrit. 4, 57.

Robertson, J. G. (1950). Brit. Y. Nutrit. 4, 49.

van der Post, A. P. (1950). Brit. Y. Nutrit. 4, 63.

\section{Commonwealth Contributions and British Requirement of Cereals}

\section{By A. Green, Spillers Ltd. Central Laboratory, Station Road, Cambridge}

\section{Wheat}

Protein content. Wheat has received most attention from this morning's contributors, and the Australian (Heywood, 1950) and the Canadian (Robertson, 1950) representatives have both shown the importance to Great Britain of their countries' wheat and flour exports. Furthermore, we can safely accept Col. Robertson's statement that Canada's wheat 'is the very best in the world'. The Canadian system of grading its wheat according to certain standard characteristics of quality is a model, but the criteria which are applied do not include any for nutrient factors, and it is with them that this Society is most concerned. Nevertheless, the nutritive value of Canadian bread-making wheats is high, and their protein contribution to our diet is important. The Scientific Adviser to the Ministry of Food, Dr Norman Wright, has recently said that wheat-flour products provide about one-third of our total protein (Wright, 1949). Our native wheats and those which come to us from Australia have relatively low protein contents and can be balanced satisfactorily only by the liberal use of high-protein wheats of the Canadian 